\title{
A simple airlift-operated tank for closed-system culture of decapod crustacean larvae and other small aquatic animals
}

\author{
P. A. Sandifer ${ }^{1}$, P. B. Zielinski ${ }^{2} \&$ W. E. Castro ${ }^{2}$ \\ ${ }_{1}^{1}$ Marine Resources Research Institute, \\ South Carolina Wildlife and Marine Resources Department; \\ Charleston, South Carolina, USA \\ and \\ ${ }^{2}$ Department of Engineering Mechanics, Clemson University; \\ Clemson, South Carolina, USA
}

\begin{abstract}
KURZFASSUNG: Ein einfaches mit Luft betriebenes Zuchtgefäß als in sich geschlossenes Kultursystem für Decapodenlarven und andere kleine aquatische Tiere. Ein Kultursystem wird beschrieben, das zur Zucht von Decapodenlarven und anderen kleineren Wassertieren geeignet ist. Es besteht aus einem rechteckigen Zuchtgefäß mit schräg abfallendem Boden, an dessen seichtem Ende Wasser einströmt, so daß eine abwärtsgerichtete Bodenströmung entsteht. An dem tiefen Ende des Zuchtbeckens wird durch eingeleitete Luft das Bodenwasser nad oben transportiert, wobei an der Oberfläche ein Gegenstrom erzeugt wird. Das Wasser zirkuliert kontinuierlich durch ein Kiesfilter, das von dem eigentlichen Zuchtgefäß abgegrenzt ist. Nahrungspartikel und Planktonorganismen werden durch den hierbei erzeugten Wasserumlauf in Suspension gehalten. Die Larven des Decapoden Macrobracbium rosenbergii konnten mit Hilfe dieses Kultursystems erfolgreich aufgezogen werden.
\end{abstract}

\section{INTRODUCTION}

The use of recirculating water management systems for the intensive cultivation of marine and brackish-water crustaceans, particularly prawns of the genus Macrobrachium, is currently under investigation at the Marine Resources Research Institute. As part of the program, an existing building will be converted into a mariculture research facility and a hatchery for the mass rearing of crustacean larvae in closed water systems. Because of the configuration of the building, rectangular, rather than cylindrical, tanks will probably be used for culturing larvae. Therefore, one of the initial objectives of the program was to design a rectangular larral culture tank which could operate as a closed system and provide suitable water circulation to evenly distribute food particles and larvae and maintain food particles in suspension. A simple prototype of such a tank has been developed, based in part on the work of SALSER \& Mock (in press) concerning circulation in rectangular algae culture tanks. This 
design is presented here in the hope that it may be of use to other investigators engaged in culturing small aquatic animals, particularly crustacean larvae, in rectangular tanks and to those planning such studies.

\section{DESCRIPTION OF THE TANK}

Major features of the prototype are (1) a rectangular shape with a flat bottom sloping from one end to the other, (2) inflow of water (via airlift pumps) across the bottom at the shallow end to produce a down-slope bottom current, (3) an airlift extending across the deep end to raise water from the bottom and establish a surface counter current, and (4) a simple gravel filter through which the water can be continuously recirculated and purified. The pattern of water circulation developed in the tank maintains food particles in suspension and keeps the cultured animals nearly evenly dispersed. Two models of the prototype differing only in arrangement of the filter unit are illustrated in Figures 1 and 2. In the first model the filter and culture tank are completely separate while in the second they are divided only by a short partition.

The basic tank and filter assemblies are constructed of $1 / 2$ in $(1.3 \mathrm{~cm})$ or $3 / 4$ in $(1.9 \mathrm{~cm})$ plywood painted with a non-toxic paint and supported by 2 in $\times 4$ in $(5 \mathrm{~cm} \times 10 \mathrm{~cm})$ wooden legs. The false bottom of the filter unit is made of a rigid plastic grating material (such as is used with some fluorescent light fixtures) covered with plastic window screening (hardware cloth). Pieces of PVC (polyvinylchloride) pipe of appropriate length are used to support the false bottom. In this study a commercially available calcareous gravel (Aquarium Systems, Inc., 33208 Lakeland Blvd., Eastlake, Ohio 44094, USA) was used as filter material, but crushed mollusk shells should be equally suitable. The filter should be biologically conditioned for several weeks before use (SPOT'T 1970).

Water is moved from the filter assembly to the culture tank by two 1 in $(2.5 \mathrm{~cm})$ diameter PVC airlifts. The airlift pipes extend through the false bottom of the filter, and bubbles from an air stone at the base of each pipe lift water from beneath the filter (Figs 1,2). Pumping rates of 400 to $6001 / \mathrm{h}$ are easily maintained with these airlifts. The tops of the airlifts are connected to two vertical pipes which carry the water down to a horizontal water distribution pipe at the bottom of the tank's shallow end (Fig. 3). Water pumped through these pipes by the airlifts emerges in jets through a row of about 25 small holes (diameter: $5 \mathrm{~mm}$ ) in the horizontal pipe. The jets of water are evenly distributed across the shallow end of the tank at the bottom and are directed down the slope. Thus, the bottom water is pushed toward the lower end of the tank where a large airlift extends across the entire tank width. This airlift reinforces the down-slope flow along the bottom and establishes a counter current at the surface. The sloping bottom of the tank increases the effectiveness of the circulation pattern in maintaining particles in suspension, but satisfactory circulation patterns can be established in tanks without sloped bottoms.

The vertical vent pipes which arise where the airlifts from the filter join the water distribution assembly of the tank provide escape for the air used in pumping the water. 
In addition, foam separators can be easily attached to these vents so that they can also serve as direct current protein skimmers (SPOTTE 1970) for removal of dissolved organic material.

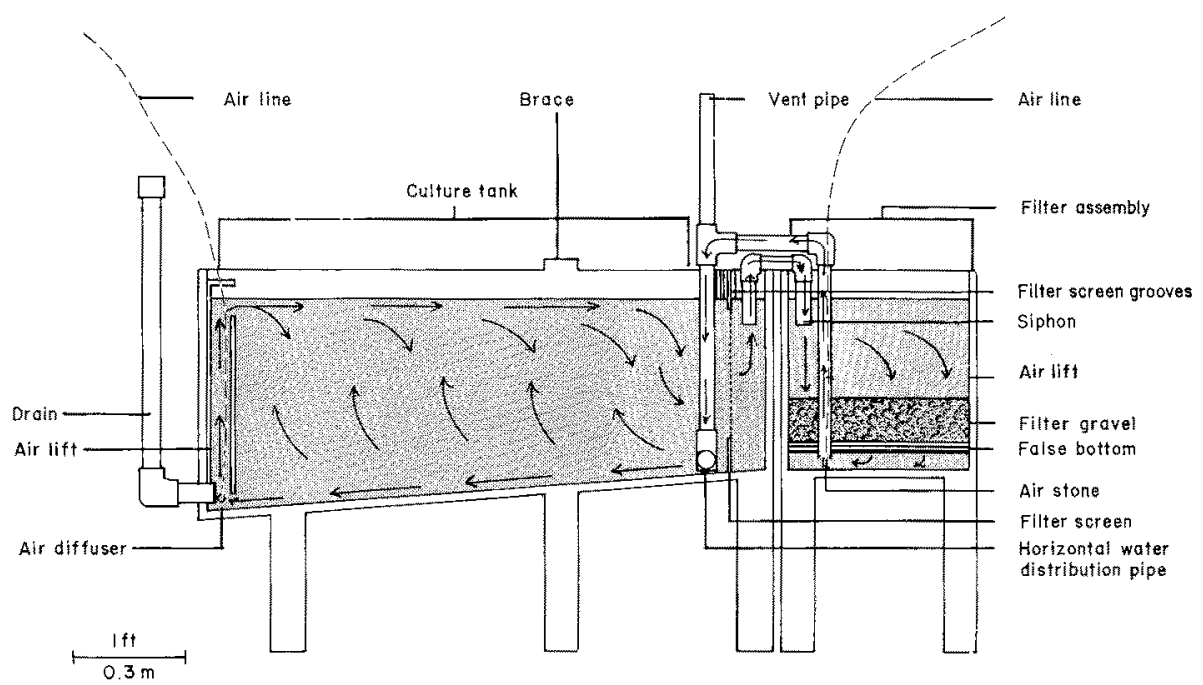

Fig. 1: Schematic side view of rectangular culture tank with separate filter. Filter unit is $2 \mathrm{ft}$ $(0.6 \mathrm{~m})$ square by 21 in $(0.5 \mathrm{~m})$ deep; culture tank is $5 \mathrm{ft}(1.5 \mathrm{~m})$ long by $2 \mathrm{ft}(0.6 \mathrm{~m})$ wide by 21 in $(0.5 \mathrm{~m})$ deep at shallow end and 27 in $(0.7 \mathrm{~m})$ deep at other end

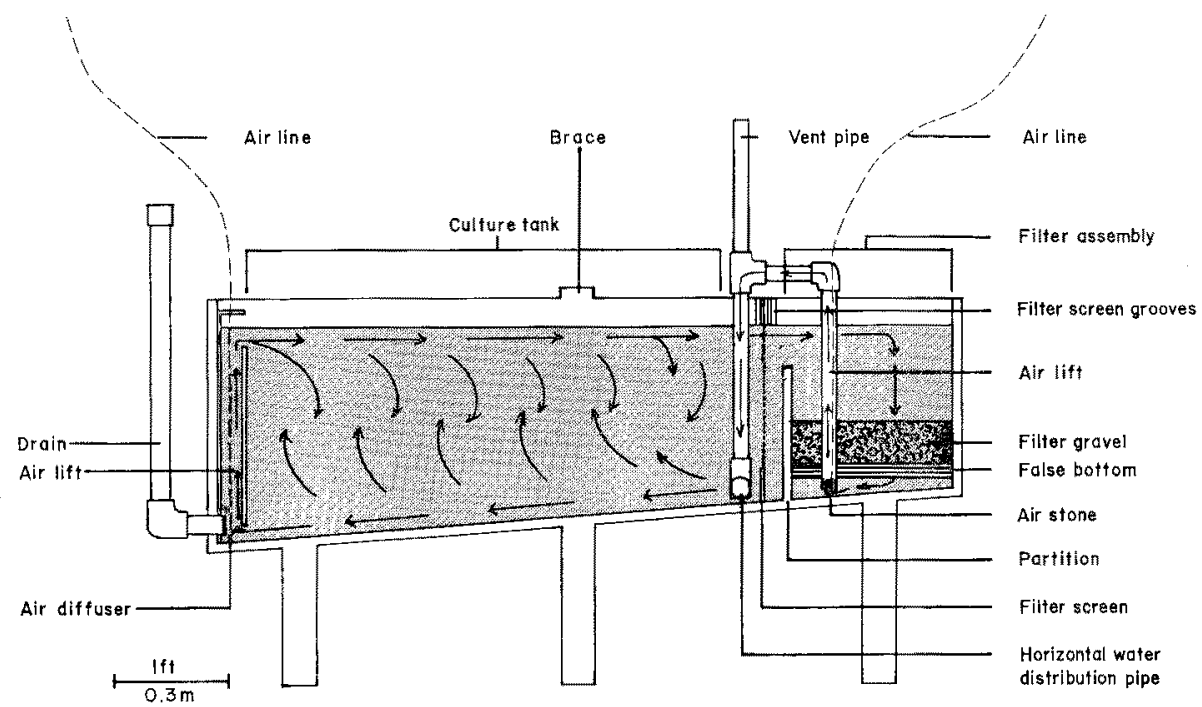

Fig. 2: Schematic side view of rectangular culture tank with filter attached. Dimensions of unit similat to those of model illustrated in Figure 1 
Immediately behind the water distribution assembly at the head of the tank are two narrow slots which extend vertically down both sides and across the bottom of the tank. A filter screen of Nitex netting attached to a Plexiglas frame fits securely in the first slot. This screen allows water to pass to the filter but prevents passage of the cultured animals. When cleaning this screen is necessary, the dual airlifts are disassembled, a second screen is placed in the alternate slot, and the first screen is then removed

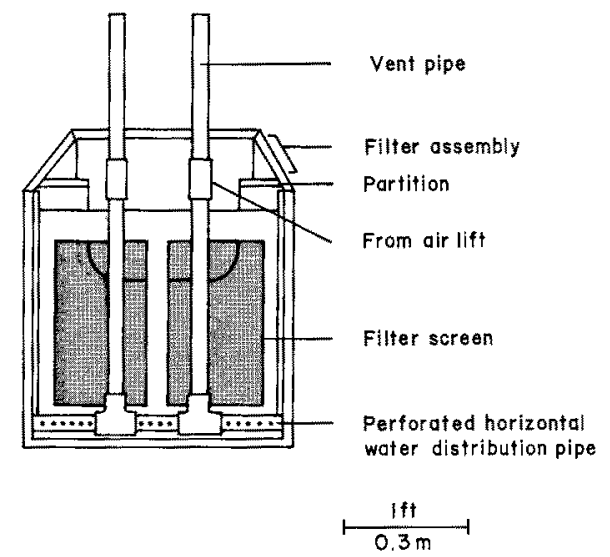

Fig. 3: Schematic front view of filter screen and water distribution assembly from rectangular culture tank

without loss of animals. After the water passes through the screen, it moves to the filter through constant level siphons of PVC pipe (Fig. 1) or simply by crossing a short partition (Fig. 2). Next, the water passes through the filter gravel and is pumped back into the culture tank by the airlifts.

When necessary, the tank is emptied through an outside drain pipe. However, since the tank is a closed system the drain is used only infrequently. During normal operation the drain opening inside the tank is sealed by a rubber stopper to prevent animals from entering it.

\section{DISCUSSION}

Interest in the use of recirculating water management systems for both laboratory culture experiments and aquaculture operations is increasing dramatically. This situation has been brought about by a number of factors, including: (1) the rising costs of locating experimental and production culture facilities for aquatic animals near adequate supplies of high quality water, (2) the increasing pollution loads in many natural waters, (3) the necessity for conserving energy in the heating or cooling of culture water, and (4) the implementation of stringent effluent quality standards in many areas. The prototype of a rectangular tank for closed system culture of crustacean larvae described here provides continuous recirculation of the culture water through a 
simple filter for purification and water circulation to keep food particles in suspension and to disperse the larvae. Tanks of this design have been employed successfully in this laboratory for culture of prawn (Macrobrachium rosenbergii) larvae and should prove satisfactory for rearing other small aquatic animals as well. In addition, the design can be easily modified for use in a flow-through water system, and the airlift pumps can be readily replaced with electrical pumps if desired.

Cylindrical tanks with conical bottoms, such as those in use at the National Marine Fisheries Service laboratory in Galveston, Texas, USA, for rearing penaeid shrimp larvae are probably the most satisfactory containers developed to date for mass culture of decapod crustacean larvae. However, such tanks are relatively expensive and cannot be constructed easily in the laboratory. Also, they may not allow maximum utilization of floor space. In contrast, rectangular tanks are relatively inexpensive and easy to build and can make possible full utilization of available space (consult ZiELINSKI et al., in press, for further discussion on the relative merits of various shapes and configurations of larval culture tanks). Rectangular tanks of the general design presented here appear to be adequate alternatives to cylindrical-conical tanks for culture of decapod crustacean larvae and can be employed in situations where the use of cylindrical-conical tanks is impractical or undesirable.

\section{SUMMARY}

1. A rectangular tank for culture of decapod crustacean larvae with continuous water recirculation is described. The tank has a sloped bottom and an attached gravel filter unit. Water circulation through the filter serves at the same time for maintaining food particles in suspension and for dispersing the larvae; it is accomplished by airlift pumps.

2. Tanks of this design have been used successfully for closed system culture of larvae of the prawn Macrobracbium rosenbergii and are expected to be satisfactory for other small aquatic animals.

Acknowledgements. This paper is contribution No. 14 from the South Carolina Marine Resources Center. This work is a result of research sponsored by NOAA Office of Sea Grant, Department of Commerce, under Grant \#NG-33-72, and by the Coastal Plains Regional Commission under contract \#10340049. The U.S. Government is authorized to produce and distribute reprints for governmental purposes notwithstanding any copyright notation that may appear hereon. Reference to trade names in this paper does not imply endorsement by NOAA Office of Sea Grant, The Coastal Plains Regional Commission, or the State of South Carolina. We thank Dr. T. I. J. Smrth, who reviewed the manuscript and offered many helpful suggestions, and we are indebted to Mr. S. Hopkins, Miss G. Kennedy, Mr. W. Trimbie, and Miss J. Williams for assistance in the laboratory. Mrs. E. MratT prepared the figures.

\section{LITERATURE CITED}

SAlser, B. R. \& Mock, C. R. An air-lift circulator for algal culture tanks. Proc. ann. Wkshp., World Mariculture Soc. 4. (In press) 
Spotte, S. H., 1970. Fish and invertebrate culture. Water management in closed systems. Wiley, New York, 145 pp.

ZIelinskx, P. B., CAS'Tro, W. E. \& SANDIfER, P. A. The evaluation and optimization of Macrobrachium shrimp larvae tank designs and support systems. Proc. ann. Wkshp., World Mariculture Soc. 5. (In press)

First author's address: P. A. SANDIFER

Marine Resources Research Institute

Charleston, South Carolina 29412

USA 